\title{
ЛІТЕРАТУРОЗНАВСТВО
}

\section{МЕТАФОРИКА ДОНБАСУ}

\author{
ЯРОСЛАВ ПОЛШЩУК \\ Університет імені Адама Міцкевича, Познань - Польща \\ yaropk@gmail.com; ORCID: 0000000190817900 \\ METAFORYKA DONBASU \\ JAROSŁAW POLISZCZUK \\ Uniwersytet imienia Adama Mickiewicza, Poznań — Ukraina
}

STRESZCZENIE. Tematem artykułu jest specyficzna metaforyka Donbasu obecna w tekstach kultury XX oraz XXI wieku. Obraz regionu został ujęty w trzech metaforach: industrialnej, sowieckiej i postindustrialnej (apokaliptycznej), które utraciły swoje znaczenie. Kształtowanie się nowej tożsamości mieszkańców Donbasu okazało się nader trudne z powodu trwałości stereotypów z przeszłości, co doskonale pokazują teksty współczesnej literatury ukraińskiej, m.in. Ołeksandry Iwaniuk, Wołodymyra Rafiejenki, Ołeksija Czupy, Lubow Jakymczuk etc.

Słowa kluczowe: metaforyka Donbasu, obraz regionu, nowa tożsamość, stereotyp, współczesne teksty literackie.

\author{
METAPHOR OF THE DONBAS \\ YAROSLAV POLISHCHUK \\ Adam Mickiewicz University, Poznań — Poland
}

ABSTRACT. Metaphor of the Donbas is the main subject of the analysis in the suggested article. We can find it in the texts on the culture, which belong to the period of the 20th and the beginning of the 21 st century. The image of this region is formed by three metaphors: industrial, soviet and post-industrial. For today they have lost their function. The process of creating of a new identity is very difficult because of the negation of the stereotypes of the past. It is reflected in the contemporary literary texts by Oleksiy Chupa, Oleksandra Ivaniuk, Volodymyr Rafeyenko, Liubov Yakymchuk.

Key words: metaphor of Donbas, region image, new identity, stereotype, contemporary literary texts.

$\prod$ ривертання посиленої суспільної уваги до Сходу України стало не тільки особливістю політичних преференцій української влади, а й своєрідним трендом в інтелектуальній творчості та різного роду аналітиці. Прикметно, що в такому розрізі проблеми ідентичності Сходу досліджуються не тільки на сучасному рівні, здійснюється їхня екстраполяція на минуле, а також прогноз щодо розвитку в майбутньому. Справи Донбасу вже не сприймаються як виключно регіональні, їх ставлять у ширший геополітичний, культурний, історичний контексти. I це цілком слушно, адже війна виявила гостроту низки питань, що роками не мали свого вирішення й були на певний спосіб замовчувані або симульовані владою. Донецька проблема стала найбільш виразним проявом ідентичнісної кризи, яку переживає посткомуністична Україна. 
Незважаючи на те, що розвиток нових ідентичностей у посткомуністичній Україні був назагал сповільненим, донецька проблема навіть на цьому тлі виглядала особливою. 3 одного боку, регіон виразно пролонгував, експлуатуючи на різні лади, радянську свідомість. 3 іншого ж боку, на Донбасі інтенсивно розвивалися нові капіталістичні відносини, що ламали стереотипи й схеми, тобто інтригували обіцянками народження чогось принципово нового. Бурхливе ж нарощення капіталу не супроводжували радикальні якісні зміни, як можна було сподіватися ${ }^{1}$. Більше того, відбулася своєрідна гальванізація свідомості homo sovieticus, що цілком не відповідає новим обставинам буття в XXI ст. Зрозуміти таку невластиву суміш непросто. Утім видається можливим кваліфікувати ії як продукт напіврозпаду радянської ідентичності: можливо, несподіваний, але логічно вмотивований самим феноменом homo sovieticus як ідентичності гібридного характеру, що схильна до незбагненних мутацій. Саме так іiі розумів Роман Шпорлюк, який в есеї Націоналізм після комунізму (1998) застерігав імовірність подібних мутацій: „Стандартна поведінка представників цієї верстви - бути радянською людиною вранці, росіянином удень та українцем увечері (послідовність може змінюватися). На цьому етапі неможливо передбачити, чи вони поступово обмежаться якою-небудь однією, конкретною формою національної ідентичності (російською, українською чи білоруською), чи виникнуть якісь нові регіональноідеологічні форми самоідентифікації, щось на зразок донбаської регіональної ідентичності з радянськими політичними й культурними ідеалами, яка не буде ані російською; ані українською. [...] Епоха після 1991 року не стала лише поверненням до 1917-1920 рр.: комунізм таки залишив по собі значну соціальнопсихологічну спадщину, яка пережила його політичну й інституційну смерть"2.

Недавні події це рішуче довели, оприявнивши незавидну роль Донбасу як живої рани невдалої української модернізації. Утім, недостатньо констатувати помилки минулого, сьогодні слід виробити певний план їхнього усунення та стратегію розвитку регіону в майбутньому. Відверте обговорення стану внутрішньої роз'єднаності в актуальних умовах наражається на критику не тільки конструктивну, а й деструктивну, оскільки воно може бути легко використане для очорнення образу України поза їі кордонами. Суперечка про реальну суб'єктність донецького регіону поки що переходить активну фазу й не видно ознак, щоб вона небавом закінчилася.

Так чи інакше, існує певне коло питань, навколо яких зібралося чимало спекуляцій та які й сьогодні викликають досить-таки гарячі дискусії й контраверсії. Серед таких питань - коди культурної ідентичності мешканців регіону. Специфіка Донбасу як регіону в різні часи проявлялася по-різному. Иого стереотипний образ пов'язаний з найбільш міцно вкоріненим типом радянської цивілізації, що жила в системі власноруч витворених міфів (міф про героїчну працю шахтарів - наріжний у цьому випадку). Однак після розпаду СРСР ця цивілізація, взагалі потерпівши тотальну поразку, зберегла свою ідентичність у кількох специфічних анклавах, із яких Донбас - чи не найбільш показовий. Характерна тенденція цих часів полягала в тому, що окремі території виявились білими плямами на тлі суспільно-політичної трансформації поч. 90-х рр. XX ст., вони певною мірою самоізолювалися від загальних процесів. „Радянська іден-

${ }^{1}$ Див. про це: Г. Х. Куромія, Свобода і терор в Донбасі. Украйнсько-російське прикордоння. 1870-1990-і роки, пер. 3 англ. Г. Кьоран, В. Агеєв; передмова Г. Немирі, Київ 2002; M. Studenna-S trukwa, Ukraiński Donbas. Oblicza tożsamości regionalnej, Poznań 2014.

${ }^{2}$ Р. Ш Порлюк, Формування модерних наиій: Украӥна - Росія - Польща, пер. 3 англ. Г. Касьянова, М. Климчука, М. Рябчука та ін., вид. 2-е, Київ 2016, с. 90. 
тичність зберігається переважно серед населення «червоної смуги» колишнього Радянського Союзу, - твердив уже згаданий політолог Р. Шпорлюк, і відданість цих людей радянським цінностям спокушає назвати їх луддистами посткомуністичної ери"з. Донбас, власне кажучи, був такою базою, через що, успадковуючи радянську модель, він виявився відпорним на зміни нового часу, анахронічним у своїх загальних орієнтаціях.

\section{Три метафори Донбасу}

У нинішніх умовах конфлікт різних ідентичностей у межах однієї держави, якою є Україна, набув вибухового характеру ${ }^{4}$. Хоча в історичному сенсі стереотип радянського Донбасу - лише одна з метафор, що характеризує минуле цього регіону. І ця метафора зафіксована у свідомості через те, що вона тривалий час упроваджувалася в життя через тексти. Колективна ідентичність у цьому разі, як видно, створена не стільки на підставі соціально-економічних чи політичних реалій (як могло би здаватись), скільки на підставі їі літературнокультурної текстуалізації: „Еволюція метафор Донбасу пов’язана 3 тим, що територія отримала символічну назву, і вона завдяки літературі, історії та політиці закріпилася. Згодом до символічних метафор додаються певні екзистенційні буттєві значення. У свідомості людей вони настільки тісно закріплюються, що ми вже не розуміємо, коли і як з'явилися ці ідеї та як нині на нас впливають. Згодом метафори перетворюються на усталені тексти, і як тільки ми кажемо «Донбас», то у нас асоціативно виникає: «край вугільний», «край праці». Все це винесено з літератури і закріплене в текстах, які дотичні до літератури"э.

Метафори Донбасу, справді, стали продуктом масової культури. Зокрема, радянський образ цього краю міцно пов'язаний з літературою соцреалістичного штибу (головно, російською та російськомовною), кіно, театром, масовою пропагандою. Радянська пропаганда впродовж тривалого періоду (особливо в 30-50-ті роки XX ст.) цілеспрямовано утверджувала культ робітничої праці (шахтарів та металургів), а також пов'язаний з ним образ нового соціалістичного побуту, що мав супроводжувати народження нових міст та агломерацій. Байдуже, що такий образ найістотнішим чином розходився з реаліями життя мешканців Донбасу. Це легко проілюструвати на наочному прикладі архітектури того часу. Планування нових міст, де мали замешкати сотні тисяч робітників та їхніх родин, велося за подвійними стандартами, із поєднанням “офіційного" та “неофіційного” будівництва. Такі подвійні стандарти досить добре репрезентували особливості радянської політики, що парадоксальним чином поєднувала в собі помпезність та убогість. Так, офіційний центр типового соціалістичного міста справляв монументальне враження, у ньому замешкувала компартійна еліта. Такий центр зусібіч „був оточений величезними барачними поселеннями, позбавленими елементарних зручностей і будь-яких можливостей для повноцінного відпочинку та незалежної громадської активності”б. Це мало утвер-

${ }^{3}$ Там само.

${ }^{4}$ C. Дорош, “Донбаський вузол”: иіна повернення Донбасу, [в:] Електронний ресурс: http:// www.bbc.com/ukrainian/politics/2016/07/160606_donbass_mentality_identity_sd (15.12.2017).

${ }^{5}$ I. Левченко, Метафори Донбасу: як писалася історія регіону в літературі, [в:] Електронний ресурс: http:/www.chytomo.com/news/metafori-donbasu-yak-pisalasya-istoriya-regionu-vliteraturi (20.12.2017).

${ }^{6}$ Д. Хмельницкий, Сталинизация советского градостроительства в начале 30-х годов, [w:] “Obóz”, zeszyt 48, t. 1: Miasta nowych ludzi. Architektoniczna i urbanistyczna spuścizna komunizmu, pod red. Z. Grębeckiej i J. Sadowskiego, Warszawa 2007, s. 124. 
джувати віру в ідеали комунізму, так само, як і переконання, що побутові труднощі мають тимчасовий характер. Однак до розв'язання “тимчасових” проблем справа так і не дійшла, вони залишилися у спадок новій державі Україна, що постала на місці СРСР. Неймовірно ускладнив ситуацію ще й занепад індустрії наприкінці XX століття, що призвів до глибокої кризи та численних соціальних, побутових і демографічних негараздів у функціонуванні східного регіону.

Упродовж XX ст. загалом були витворені та функціонували принаймні три метафори Донбасу, кожна з яких відображала стан регіону та його значення в країні ${ }^{7}$. Так, перший образ сформувався ще на межі XIX-XX століть, а його основними атрибутами були степ і важка фізична праця. Друга асоціація пов'язувала Донбас із радянською індустріалізацією та героїчною працею. Саме вона й стала осьовою для свідомості мешканців регіону, а також була надовго зафіксована в радянському суспільстві. Натомість третя, остання метафора, що набуває чинності в наш час, заступає другу й заперечує їі: вона трактує Донбас як зону цілковитої кризи, дегуманізації й екзистенційної порожнечі.

Три метафори, що вказують на різні способи міфологізації терену, відображають характерні стани регіону: 1) початок індустріальної колонізації краю; 2) перетворення у провідну зону радянської індустрії та іiі взірцеву агломерацію; 3 ) криза регіону, що вичерпує свій економічний потенціал і разом 3 тим виявляє системні недоліки, приховувані раніше. Серед останніх найбільш вразливою видається криза гуманізму, що стала результатом занедбання роботи з людиною, нехтування соціальними чинниками розвитку суспільства. Це контраверсійним чином позначилося й на актуальній ситуації, у якій людина опинилася в ролі вигнанця, який покутує гріхи політиків, олігархів, та владоможці, при цьому самі причетні до гуманітарної катастрофи краю, уникають оскарження та перекладають відповідальність за свої дії на інших.

Образ виснажливої й небезпечної праці в культурній свідомості донеччан витіснив інші реалії життя, зокрема нові капіталістичні порядки, що набули чинності в останні часи. У репрезентації ідентичності краю він нерідко стає ключовим, як-от у відомій поемі Любові Якимчук Абрикоси Донбасу (2013). Авторка, щоправда, апелює не стільки до радянської, як до доісторичної (скіфської, степової) пам'яті Сходу, зіставляючи її із сучасним станом кризи та руїни. На думку поетеси, сьогодні Донбас схожий на людське тіло, що розкладається:

Зачекай!

Ця шахта ковтне тебе

Ця красуня з темною шкірою

Кам'яна

Може, це їй скіфи поставили пам'ятники

Серед неголених як шахтарі степів

Зачекай!

Вона народить тобі мертве море

Iї талія не 60

А груди обвисли до пояса

Не заходь у неї

Можеш не повернутися

Мов дитина в матері

Яка не хоче народжувати ${ }^{8}$

${ }^{7}$ І. Левченко, Метафори Донбасу: як писалася історія регіону в літературі...

8 Л. Якимчук, Абрикоси Донбасу (поема), [в:] Електронний ресурс: http://sho.kiev.ua/ article-sho/5361 (11.12.2017). 
У поемі Любові Якимчук своєрідно поєднуються вказані вище метафори, а разом $з$ тим відчувається спроба конструювання якоїсь іншої тотожності, що увібрала $б$ у себе досвід минулого, але й означила перспективу розвитку. На жаль, нинішні обставини, у яких цей край опинився (хоча - певною мірою їх можна було б поширювати й на всю Україну в ії непевній та перехідній якості), не дають змоги таку перспективу окреслити. Тотальна криза занурює Донбас у хаос та невизначеність, а тривалість перебування в мертвій точці цивілізації навряд чи можна визначити. Сдине, на що вказують і аналітики, й письменники, - це те, що нинішні процеси мають незворотній характер, а повернення до status quo, який існував іще кілька років тому, абсолютно неможливе. Тектонічні зсуви, що забезпечили воєнний конфлікт і відчуження населення краю, ще по-справжньому не пізнані.

\section{Зона розпаду}

“Живий”, пропущений крізь вразливе емоційне сприйняття героя, образ донецького конфлікту подає молода авторка Олександра Іванюк у романі $A$ мор $[\mathrm{m}] e$ (2017). Війна з'являється в ньому як тло, але згодом переростає в один з провідних мотивів, ламаючи сюжетну тяглість історії. Так раптово вона вривається в приватне життя персонажів, не тільки порушуючи гармонію їхніх стосунків, а й викликаючи тривалу кризу, згодом обертаючись трагічними переживаннями. Конкретна людська доля опиняється заручником якогось злого генія, що раптово ламає звичний уклад життя та заражає все довкола духом агресії й ненависті. Важливо й інше: авторка пропонує плавне входження в тему, зображує Донбас напередодні подій 2014 року. Вона поступово відстежує ті тенденції, які призвели до громадянського конфлікту в регіоні, тобто зображує, сказати б, історію хвороби, унаслідок якої трапилася воєнна трагедія. Показує, як покроково на Донбасі наростав цей дух зла й нетерпимості, що, урешті, вибухнув кривавим протистоянням. І в цьому слід визнати їй рацію, адже вибудуваний авторкою причинно-наслідковий ланцюжок виглядає переконливим, принаймні, настільки, щоб пояснити неспокійну поведінку та непередбачувані вибори ії персонажів.

В основі твору - доволі нетиповий, оригінальний задум. Олександра Іванюк підходить до висвітлення теми зі зворотної перспективи, себто зображує Донбас не безпосередньо, а через своєрідні окуляри, і так само опосередковано спостерігає розвиток суспільного конфлікту. Такий ефект забезпечує незвичний ракурс: у романі оповіджена історія від імені іноземки, що опиняється в Донецьку й проводить у ньому певний час, несподівано потрапляючи в сам вир подій. Відповідно, маркування простору здійснюється не шаблонно, воно стає можливим через постійні порівняння, які у своїй уяві “програє” героїня твору. Ї̈і пізнання Донбасу відбувається на тлі зіставлень з іншими європейськими країнами, звідси виникають цілком логічні екзотичні враження, що їх фіксує протагоніст роману. 3 одного боку, це дає можливість оцінити поведінку й ментальність "донецьких" із позицій європейської ідентичності, носієм якої є головна героїня роману. 3 іншого боку, з оповіді природно випадають деталі, які, хоч важливі для місцевих, не мають значення для когось чужого. Додаймо, що сприйняття молодої італійки, яка не знає українських (передусім регіональних, донецьких) реалій, $\epsilon$ доволі специфічним, і треба відзначити спостережливість авторки роману в ухопленні багатьох характерних деталей, що виражають ментальні відмінності й пов'язані з ними суперечності та конфузи. 
Любовна історія в центрі сюжету — це добрий прийом, що забезпечує успіх книжки Олександри Іванюк. Сюжет твору становить оповідь молодої італійки Франчески, що в ролі волонтера приїздить до Донецька, де знаходить велике й трагічне кохання свого життя - Юрія. Разюча несхожість темпераментів і характерів героїв - добра нагода, аби виявити величезні відмінності, що розділяють сучасну Європу та Україну. Перша живе спокійним, ситим і розміреним життям, задивлена в себе й заглиблена у власні проблеми. Вона не хоче знати й чути, що діється на східних їі рубежах. Україна, навпаки, непевна, нестійка, зболена й розгублена, у стані війни й загальної кризи, підсиленої внутрішнім конфліктом, що безпосередньо виявляється у воєнному протистоянні на сході держави. Україна ідеалізує Європу й прагне до неї, але не відчуває взаємності. Однак те, що в житті викликає гостре протистояння, у романі може бути злагоджено силою художньої уяви. Саме так чинить Олександра Іванюк, яка робить героєм-оповідачем романної історії молоду італійку. Через цей образ відбувається умовне поєднання Свропи й України, через посередництво Фра ці два відмінні світи починають стрімко зближуватись. Хай це тільки приватний випадок, але знаковий і перспективний.

Хоча роман позиціоновано як твір художній, авторка все-таки подала докази достовірності любовної історії, описаної в ньому9. Вона вмістила фото закоханих та біографічну нотатку про Юрія Матущака, який став прообразом героя твору, - молодого патріота, волонтера, історика, що пішов добровольцем на фронт та загинув під Іловайськом 29 серпня 2014 року. Так само й образ Франчески, як запевняє авторка, не був вигаданий: її прототипом стала реальна особа, із якою письменниця познайомилась у Варшаві і яка захотіла поділитися своєю зворушливою любовною історією ${ }^{10}$. До всього, враження документальності нерідко викликають окремі описи та сцени, подані в романі $A$ мор $[\mathrm{m}]$ $e$. Вони загалом відповідають хронології подій, що позначена наростанням напруження, а пізніше й відвертого конфлікту на Сході України в 2013-2014 p.p., також відображають основні точки цього напруження (мітинги, інші громадянські акції). Інша, значно важливіша сторона дійсності - це відтворення загальних тенденцій на прикладі конкретних персонажів, тобто спроба дослідити своєрідну ментальність мешканців Донецька. У цьому разі вона тим цікавіша, що цю ментальність описує - часом зі здивуванням і зацікавленням, іноді з нерозумінням та обуренням - іноземка, яка й місцеву мову не дуже розуміє, і звичаї не приймає.

Нарешті, переконливості й вірогідності історії надає фінальний розділ, що складається з листів Франчески до Юрія. Це листи в нікуди, бо їм уже не суджено дістатись до адресата й бути прочитаними ним. Писані в стані тривоги й страху, як спроба автотерапії, а також як відчайдушний жест - урятувати кохану людину. Це листи у страшну невідомість, що згодом обертається смертю. Вони вірний документ людського страждання, що стає побічним продуктом цієї війни. Проте для читача роману саме такий документ важливий, він набагато цінніший, ніж нариси донецького життя, які можна прочитати й деінде. До всього, він править за блискуче завершення всієї любовної історії; тобто означує ії відкритий фінал, що залишає нерозгаданою любовну таємницю.

${ }^{9}$ О. Іванюк, Я гуляла Донецьком по Google Maps, [в:] Електронний ресурс: http://www. bbc.com/ukrainian/in-depth-42080988 (10.11.2017).

${ }^{10}$ Там само. 
Зворушлива історія людського кохання - ось що інтригує читача й виходить поза рамки соціально-політичних реалій (Донбас - Україна - війна). Вона апелює до універсальних почуттів та емоцій - поза поділами на мови, нації, політичні погляди, соціальний стан тощо. У цьому бачиться сила художнього пафосу роману Олександри Іванюк. Однак не можна ігнорувати в цьому контексті силу “локального" чинника, адже саме він визначає гостроту сюжетних колізій твору й те внутрішньо-психологічне напруження, яке весь час супроводжує оповідь (роман написано у формі автобіографічної сповіді героїні post scriptum, після втрати коханого та виїзду з України). Франческа намагається пізнати характер Юрія і весь час бореться із собою, вагаючись між власними почуттями до героя (що видаються їй егоїстичними) та розумінням того особливого призначення, яким він живе і яке становить основу його ідентичності.

Для хлопця Донбас - місце не випадкове. Він переконаний, що може реалізуватися саме тут, незважаючи на величезні труднощі, яких зазнає. Адже в іншому місці, як зізнається Юрій, не матиме значення все те, що він робить, „це наче відмовитись від себе самого". Будучи активним громадянином і патріотом, Юрій формує місце свого замешкання, надає йому іншої ідентичності, ніж була раніше, замінюючи радянські цінності на українські та ліберальні. Характерні епізоди, де він бере участь у впорядкуванні могил італійських вояків із часу Другої світової війни або ж апелює до козацької традиції в історії краю: так Юрій повертає витіснену історичну свідомість. Біда в тому, що такі ініціативи поодиноких активістів не мають загальної підтримки - ані на рівні влади, ані в суспільній думці. „Місця пам’яті, навіть офіційні, подають себе як такі, коли лише кристалізують консенсус або колективну згоду"11. Тому зусилля героя приречені на несприйняття й невдачу в середовищі земляків. Разом з тим Франчесці доводиться пізнати зворотний бік самовідданого патріотизму, що витісняє на узбіччя приватні інтереси й, зрештою, унеможливлює власне щастя.

Донбас у художньому зображенні Олександри Іванюк постає як простір заражений, викривлений, порожній. Він позбавлений істотних властивостей, без яких не має шансів на майбутнє. Це край у стані розпаду, причому спочатку такий стан зафіксований у головах мешканців, а вже пізніше проявляється в дійсності, провокуючи низку відповідних подій. Апелюючи до відомої теорії Марка Оже, можна сказати, що Донбас у романі означено як типове не-місце, транзитний пункт, у якому людське життя не знаходить комфорту, а тільки тимчасове пристанище - необлаштоване, перехідне, тривіальне.

Отже, можна сказати, що Донбас у романі $A м о р[m] е$ означений як типове не-місце, тобто транзитний пункт, у якому людське життя не знаходить комфорту, але бачить тільки тимчасове пристанище, необлаштоване, тривіальне, перехідне. У таких місцях не хочеться жити, адже вони представляють простір, який не можна дефініювати ані як ідентичнісний, ані як зв'язковий, ані як історичний ${ }^{12}$. Це добре відчувають донеччани, зображені в Амор $[m] e$, тому прагнуть за будь-яку ціну покинути місто. Серед них учні Франчески, які навчаються італійської, щоб емігрувати. I навпаки, сама Фра за прикладом свого коханого Юрія, схильна сприймати Донбас серйозно, не як транзитну зону. Це, урешті, визначило її вибір, адже приїхала сюди добровільно і так само добровільно залишилась у непевні часи, щоб бути разом зі своїм хлопцем. Фра стає до-

${ }^{11}$ П. Нор а, Теперішнє, нація, пам'ять, пер. $з$ фр. А. Рєпи, Київ 2014, с. 245.

${ }^{12}$ M. A ugé, Nie-miejsca: wprowadzenie do antropologii hipernowoczesności, tłum. R. Chyłkowski, przedm. W. J. Burszta, Warszawa 2010, s. 53. 
брим прикладом громадянської відповідальності для свого оточення, причому як у апатичній Україні, так і в самодостатній Італії.

Однак реалії Донбасу показані у творі досить жорстко, без прикрас. Передусім Франческу дивує культура краян, котрі не люблять одне одного, недовірливі й злі, а своє місто вважають тільки вимушеним пунктом, із якого мріють якнайшвидше виїхати. Поверхова екзотика Донбасу обертається для Фра емоційним шоком, коли вона глибше пізнає ментальність місцевих людей і не знаходить у ній продуктивних цінностей, на яких тримається зазвичай громадянське суспільство в Свропі. Ситуація буття на межі поширюється не тільки на перші дні побуту іноземки в незнайомому місті (що цілком зрозуміло), а й на кожен наступний день, який може бути сповненим неприємних інтриг та пригод. Це дає підстави до таких міркувань: „Все ж таки життя в Донещьку це суиільне пекло, у якому кожен зустрічний намагається пошити тебе в дурні. Я досі жодного разу не зустріла чесного таксиста або продавия на базарі. Коли дізнаються, щз я - іноземка, - щзо не складно почути в перші п'ять секунд розмови, - мене одразу намагаються ошукати, використати або втягнути у шзось таке, як торгівля шлюбами. Господи, тут наче всі зациклені на якомусь зиску, шахрайстві, втечі за кордон і бозна на чому щзе"'13.

Жити в такому не-місиі не тільки некомфортно й незручно, а й небезпечно. Теорія не-місия може бути вдалим поясненням пасивності мешканців Донбасу, які то утримуються від власної думки, то виявляють необгрунтовану агресію, коли хтось інший вирішує їхню долю. У романі О. Іванюк тільки головні герої (Юрій, Фра, та ще частково їхні друзі й родичі) намагаються протистояти цьому магічному впливу не-місця як “чорної діри", наповнюють транзитний простір власною харизмою, надаючи йому тим самим певних властивостей. Щоправда, це обертається зависокою ціною для них самих, оскільки змушені жертвувати або власним життям (як Юрій), або ж коханням і щастям (як Франческа).

Відсутність колективної ідентичності в цьому разі відіграє фатальну роль. Тотожності, що пов'язують донецький край з його минулим, вже однозначно спрофановано, вони не об'єднують людей. Стан розпаду й тотальної кризи характеризує не тільки свідомість мешканців регіону. Він певною мірою поширюється на кожного, хто в цьому терені опиняється й пробує реалізувати власні амбіції. Це добре відчуває героїня роману О. Іванюк. Вона декларує: „,... Яне зобов'язана любити цүю краӥну — вистачить любові до кароокого. Ділити його з нею і є найбільшою жертвою, на яку - вимушено - але доводиться йти. Та ніхто не може змусити мене любити Донецьк, який навіть сам себе не здатен любити, заперечуючи будь-які спроби - і навіть саму ідею - розвиватися у згоді з рештою країни. [...] Важко позбутися враження, наче Донецьк - навіть з їхнім президентом, який з того, щуо я чула від кароокого, перевіз до столиці всю місцеву еліту, - оточений ворогами і постійно, як те болото, змушений відстоювати власну екосистему. I ия його болотистість, щзо ладна занурити у себе живцем кожного незгодного, - викликає в мене огиду й небажання співчувати нічому й нікому тут"'14.

Колективний портрет мешканців Донецька - гостро критичний, хоча й не однозначний. Карикатурний - у тій частині, де авторка розвінчує звичайних обивателів чи випадкових знайомих. Компліментарний — тоді, коли Франческа оцінює Юрія та його товаришів-патріотів, які намагаються протистояти знево-

\footnotetext{
${ }^{13}$ О. І І а н юк, Амор $[m] е:$ роман, Чернівці 2017, с. 99.

14 Там само, с. 204.
} 
люючій владі не-місия. Збірний образ Донбасу, що постає в романі, вартий докладнішого аналізу. Він містить певні елементи того, що має стати (і неодмінно стане) предметом серйозної рефлексії інтелектуалів. Мова про локальну ідентичність, яку репрезентують (кожен по-своєму, у ії мозаїчній різноманітності, але й у слабкій, найчастіше нерозпізнавальній якості) персонажі роману.

\section{Потреба нових смислів}

Розмова про регіональну тотожність Донбасу силою обставин приречена на заангажованість, адже нині на цій землі точиться війна, а ії гібридний різновид - як інформаційно-медійне протистояння та змагання новітніх технологій маніпуляції масовою свідомістю - робить цей об’єкт особливо складним, вразливим та непередбачуваним для аналізу. Загадка ментальної, політичної та культурної відмінностей донецького регіону існувала впродовж усієї короткої істоpiї незалежної України: вона то перебувала в центрі публічної уваги, то, навпаки, сходила на маргінес. Без перебільшення можна твердити, що донецька ментальність - хотіли б ми того чи не хотіли - $є$ невід'ємним складником творення молодої держави. Від того, наскільки вона виразна й наскільки поєднується з іншими регіональними тотожностями України, залежить успіх самої країни загалом. 3 одного боку, донецький регіон - один з наймолодших у сучасній Україні, що пояснює невиробленість та невиразність його сучасної метафори. 3 іншого боку, у час воєнного протистояння саме Донбас став своєрідною призмою, у якій переломлюються різні проекти та моделі нової ідентичності, що іiі має набути Україна XXI ст.

Ще в 30-i pp. XX ст. почалося творення радянського культу цього регіону 3 акцентами на самовіддану й доблесну працю гірників. Із цього культу народився й “стахановський рух", що тоді охоплював усю країну, хоча пізніше виявився тільки пропагандистським міфом. Якщо в 30-і pp. XX ст. його творили, головно, московські письменники та публіцисти, спеціально відряджені на Донбас, то після війни до цього долучилися й місцеві автори. Так, у 40-х рр. XX ст. у Донецьку почали видавати альманах „Літературний Донбас”, дещо пізніше виник журнал „Донбас”, що відображав літературне життя регіону й загальну культурну політику тогочасної влади. Характерно, що українська мова в цьому часописі була цілеспрямовано маргіналізована. Провідні позиції журналу займали П. Беспощадний, П. Сєвєров, П. Чебалін, що представляли соцреалізм у його донбаській редакції, з акцентами на виробничій тематиці та шахтарській героїці. Не дивно, що чимало талановитих земляків не могли й мріяти про публікацію в „Донбасі”.

У період незалежної України чинилися спорадичні спроби переформатувати культурну ідентичність регіону, але вони були надто кволі й не мали значного ефекту. Так, зовсім недавно було видано антологію Порода (2017), що представила читачеві цілу низку визначних літераторів Донбасу, про творчість яких загалом мало відомо широкій громадськості. Читач цього альманаху сприймає інший, зовсім відмінний від радянського й соцреалістичного, образ краю: на це “працюють” художні тексти Василя Стуса, Івана Світличного, Івана Савича, Леоніда Талалая, Василя Старуна, Василя Голобородька та ін. ${ }^{15}$. Одначе такий образ надалі лишається екзотичним. Ідеться не тільки про українськомов-

${ }^{15}$ Порода: Антологія украӥнських письменників Донбасу, упор. В. Білявського і М. Григоріва, передм. І. Дзюби, Київ 2017. 
ну творчість, а й про культурну орієнтацію численних авторів, які пов'язували себе з українським Сходом, а не пролетарською російською літературою, що опинилася в ситуації подвійної маргіналізації: а) як провінційний варіант російської словесності; б) як тематичний і стильовий “тупик”, оскільки обмежувалася наслідуванням московських зразків офіційної культури. У творах згаданих авторів зображена ситуація індивідуального бунту проти загального знеособлення й цинізму.

Нині небагато письменників, які не тільки походженням пов'язані з Донбасом, а й уважають цей регіон основним об'єктом свого художнього зображення. Це Володимир Рафєєнко, Олена Стяжкіна, Олексій Чупа, Любов Якимчук, Олег Соловей, Олена Степова та ін. У їхніх творах наштовхуємося на певну суперечність, що, очевидно, є характерною ознакою теми. Мова про те, що персонажі-краяни переважно уникають виявлення своєї індивідуальності — чи то під дією суспільної мімікрії, чи то через інші причини. Їхня свідомість більше залежить від загальних норм, звичаїв, стереотипів, а якщо й спромагається на бунт супроти цих норм, то це буває бунт непередбачуваний і стихійний, часто не осмислений, а відтак і не результативний. Отже, маємо справу зі зрощенням індивідуальної тотожності з колективною, що надзвичайно ускладнює можливість диференціації цих двох чинників. Зображуючи донеччан, письменники прагнуть виявити своєрідний психотип людини, але також і відповісти на питання про локальну ідентичність, що лишається предметом гарячих суперечок сьогодні.

Художні типи, зображені в сучасній літературі, утілюють ментальність межового характеру: виразно не проявлена у звичайних обставинах, вона може набувати категоричних форм і провокувати насильство та агресію у гострих ситуаціях. У персонажів обох донецьких письменників можна зауважити брак індивідуальних властивостей $\mathrm{i}$, навпаки, домінування певних суспільних стереотипів поведінки, що має за завдання цей брак приховати. Окремо можна говорити про біологічні властивості цих типів, реакції тіла (біль, страх, страждання), які багато що визначають. Та якщо на рівні біологічному ці реакції цілком виразно проявляються, то з акцептацією норм соціальної поведінки тут $\epsilon$ проблема. Невизнання або сліпий бунт проти соціальних норм приховують відсутність певної морально-етичної традиції, а також пам'яті про минуле. Як бачимо, донецьку ідентичність можна сприймати як непрямий наслідок радянського експерименту, що зводився до заперечення традиції та утвердження абсолютної влади та стихійного права сильного. 3 іншого боку, це ознаки своєрідної непроявленості донецького менталітету, його “непрописаності” в сучасній культурі та “анексії” в символічній географії. Адже впродовж значного часу тривала міфологізація Донбасу, а замість конкретних досліджень регіону практикувалися стереотипні погляди на його специфіку. Однак варто підкреслити, що саме творчі інтелектуали (серед них і названі письменники) активно взялися за деміфологізацію Донбасу, на відміну від інертних політичних еліт. Саме вони відверто порушують проблеми, що мають стати предметом широкого суспільного обговорення.

Метафорика Донбасу, що була текстуалізована у творах художньої літератури останніх років, виразно засвідчує ферментацію нової якості, яка постає через руйнування стереотипів, винесених із минулого. Відчуженість і самоізоляція, малодушність і брутальність, що нерідко маскуються під дивакуватість і екзотичність, - типові ознаки цього середовища. Назовні воно намагається 
видаватися сильним і самодостатнім (звідси виникає теж культ сили й насильства, що дискурсивно присутній у характерах “донецьких"), проте під цим показним образом нерідко приховується страх і безпорадність, інертність та брак волі до життєвих змін. Така суперечлива градація визначає нестабільність донецької ментальності. Вона вказує на стан екзистенційної порожнечі, що постала на місці зруйнованого колись радянського міфу, постулює кризу цінностей та моральних орієнтирів у сучасних обставинах. Як наповнити цю порожнечу новим смислом - питання для майбутньої дискусії.

\section{Список використаної літератури}

Дорош С., „Донбаський вузол”: иіна повернення Донбасу, [в:] Електронний ресурс: http://www.bbc.com/ukrainian/politics/2016/07/160606_donbass_mentality_identity_ sd (15.12.2017).

Іванюк О., Амор[m]е: роман, Чернівці 2017.

Іванюк О., Я гуляла Донеиьком по Google Maps, [в:] Електронний ресурс: http://www. bbc.com/ukrainian/in-depth-42080988 (10.11.2017).

Куромія Г. Х., Свобода і терор в Донбасі. Українсько-російське прикордоння. 18701990-ті роки, пер. з англ. Г. Кьоран, В. Агеєв, передмова Г. Немирі, Київ 2002.

Левченко І., Метафори Донбасу: як писалася історія регіону в літературі, [в:] Електронний pecypc: http://www.chytomo.com/news/metafori-donbasu-yak-pisalasyaistoriya-regionu-v-literaturi (20.12.2017).

Нора П., Теперішнє, начія, пам'ять, пер. $з$ фр. А. Рєпи, Київ 2014.

Порода: Антологія українських письменників Донбасу, упор. В. Білявського і М. Григоріва, передм. І. Дзюби, Київ 2017.

Хмельницкий Д., Сталинизация советского градостроительства в начале 30-х годов, [w:] „Obóz”, zeszyt 48, t. 1: Miasta nowych ludzi. Architektoniczna i urbanistyczna spuścizna komunizmu, pod red. Z. Grębeckiej i J. Sadowskiego, Warszawa 2007, s. 113-125.

Шпорлюк Р., Формування модерних націй: Україна - Росія - Польща, пер. 3 англ. Г. Касьянова, М. Климчука, М. Рябчука та ін., вид. 2-е, Київ 2016.

Якимчук Л., Абрикоси Донбасу (поема), [в:] Електронний pecypc: http://sho.kiev.ua/ article-sho/5361 (10.12.2017).

Augé M., Nie-miejsca: wprowadzenie do antropologii hipernowoczesności, tłum. R. Chyłkowski, przedm. W. J. Burszta, Warszawa 2010.

Studenna-Strukwa M., Ukraiński Donbas. Oblicza tożsamości regionalnej, Poznań 2014.

\section{Spysok vykorystanoi literatury [References]}

Dorosh S., „Donbaskyi vuzol”: tsina povernennia Donbasu, ["Donbas Node”: Price of Donbas Return], [v:] Elektronnyi resurs: http://www.bbc.com/ukrainian/ politics/2016/07/160606_donbass_mentality_identity_sd (15.12.2017).

Ivaniuk O., Amor[t]e : roman [Amour: Novel], Chernivtsi 2017.

Ivaniuk O., Ya huliala Donetskom po Google Maps [I Walked along The Sreets of Donetsk Surfing Google Maps], [v:] Elektronnyi resurs: http://www.bbc.com/ukrainian/indepth-42080988 (10.11.2017).

Kuromiia H. Kh., Svoboda i teror v Donbasi. Ukrainsko-rosiiske prykordonnia. 1870-1990-ti roky [Freedom and Terror in Donbas. Ukrainian-Russian Borderline Territories], per. z anhl. H. Koran, V. Aheiev, peredmova H. Nemyri, Kyiv 2002.

Levchenko I., Metafory Donbasu: yak pysalasia istoriia rehionu v literaturi [Metaphors of Donbas: the Way History of Region was Written in Literature], [v:] Elektronnyi resurs: http://www.chytomo.com/news/metafori-donbasu-yak-pisalasya-istoriya-regionu-vliteraturi. 
Nora P., Teperishnie, natsiia, pamiat [Present Day, Nation, Memory], per. z fr. A. Riepy, Kyiv 2014.

Poroda: Antolohiia ukrainskykh pysmennykiv Donbasu [Anthology of Ukrainian Writers of Donbas], upor. V. Biliavskoho i M. Hryhoriva, peredm. I. Dziuby, Kyiv 2017.

Hmelnickij D., Stalinizacija sovetskogo gradostroitelstva v nachale 30-h godov [Stalinization of Soviet City Building at the Beginning of the 30-ies], [w:] „Obóz” zeszyt 48, t. 1: Miasta nowych ludzi. Architektoniczna i urbanistyczna spuścizna komunizmu, pod red. Z. Grębeckiej i J. Sadowskiego, Warszawa 2007, s. 113-125.

Shporliuk R., Formuvannia modernykh natsii: Ukraina - Rosiia - Polshcha [Formation of Modern Nations: Ukraine - Russia - Poland], per. z anhl. H. Kasianova, M. Klymchuka, M. Riabchuka ta in., vyd. 2-e, Kyiv 2016.

Yakymchuk L., Abrykosy Donbasu (poema) [Apricots of Donbas (Poem)], [v:] Elektronnyi resurs: http://sho.kiev.ua/article-sho/5361 (10.11.2017).

Augé M., Nie-miejsca: wprowadzenie do antropologii hipernowoczesności, thum. R. Chyłkowski, przedm. W. J. Burszta, Warszawa 2010.

Studenna-Strukwa M., Ukraiński Donbas. Oblicza tożsamości regionalnej, Poznań 2014. 